\title{
ТЕРМІЧНА ОБРОБКА ЯК СПОСІБ ПОКРАЩЕННЯ ОБРОБЛЮВАНОСТІ РІЗАННЯМ ІНСТРУМЕНТАЛЬНОГО СПЛАВУ 3 ГЦК ҐРАТКОЮ
}

Для виготовлення інструментів гарячого пресування металів (матриці, голки, прес-шайби і т. і.) розроблено сплав на залізонікелевій основі ХН35В6ТЮ (ЕК39) [1] як ефективний замінник серійних високотеплостійких штампових сталей мартенситного класу типу 5Х3В3МФС (ДИ23). Сплав має ГЦК кристалічну гратку основи і зміцнюється при дисперсійному твердінні частинками $\gamma^{\prime}$ - фази типу $\mathrm{Ni}_{3}(\mathrm{Al}, \mathrm{Ti})$. Таке зміцнення залізонікелевих сплавів забезпечується легуванням їх алюмінієм та титаном [2]. Зміцнювальну термічну обробку пресових інструментів із сплаву рекомендовано виконувати за режимом: гартування $1150^{\circ} \mathrm{C}, 2$ години, масло + старіння $780{ }^{\circ} \mathrm{C}, 10$ годин. Однак, незважаючи на більш високу працездатність, широке використання сплаву стримується порівняно гіршою, а відповідно і більш витратною, механічною оброблюваністю різанням порівняно з серійними штамповими сталями. Це властиво для усіх сплавів з ГЦК кристалічною граткою внаслідок більшої схильності до наклепу, адгезії (схоплення), підвищеного нагріву та інших особливостей в зоні різання $[3,4]$. Робота присвячена пошуку такого стану сплаву, для якого його оброблюваність різанням є найменш витратною.

Для досліджень використовували ковані прутки сплаву діаметром 95 мм. Механічну оброблюваність різанням визначали в наступних станах: стан постачання (твердість $32 \mathrm{HRC})$; гартування $1150{ }^{\circ} \mathrm{C}, 2$ години, масло (75 HRB, тобто менше нижньої границі вимірювань за шкалою «С»); гартування + старіння $780{ }^{\circ} \mathrm{C}, 2$ години (27 HRC); гартування + старіння $780^{\circ} \mathrm{C}, 10$ годин (33 HRC). Вказані стани відповідають різним послідовним стадіям виготовлення (термічної обробки) пресових інструментів із сплаву. Структура сплаву в стані постачання відповідала деформованому (після) стану з неконтрольованим утворенням частинок зміцнювальної $\gamma^{\prime}$ - фази. В загартованому стані сплав мав структуру пересиченого твердого розчину без частинок $\gamma^{\prime}$ - фази. У випадку наступного старіння при температурі $780^{\circ} \mathrm{C}$ протягом 2-х годин розпад пересиченого твердого розчину був неповним (недостарювання) - частинки $\gamma^{\prime}$ - фази мали середній розмір 10 нм при їх об’ємній частці $5 \%$. При старінні $780{ }^{\circ} \mathrm{C}$ впродовж 10 -ти годин дисперсійне твердіння сплаву відбувалось найбільш повно, що забезпечило максимально можливу вторинну твердість. Об’ ємна частка $\gamma^{\prime}$ - фази при цьому зростала до $13 \%$, а середній розмір частинок досягав 23 нм.

Оцінку механічної оброблюваності сплаву виконували за результатами визначення залежності стійкості різального інструменту $\tau$ (в хвилинах) від швидкості різання v (в м/хвилину). Використовували різальні пластини зі швидкорізальної сталі марки Р6М5К5. Проводили точіння вздовж прутка на токарно-гвинтовому верстаті (модель ГК62М) при наданні 0,39 мм/оберт і глибині різання 1 мм. Величину швидкості різання змінювали від 0,5 до 20 м/хвилину.

За отриманими результатами побудовані графіки відповідних залежностей, які, як показано на рис. 1 в координа$\operatorname{Tax} \lg \tau-\lg v$, мали вигляд майже паралельних (для різного стану сплаву) прямих, зручних для аналізу. 3 порівняння ходу таких прямих встановлено, що при усіх швидкостях різання значення стійкості різальних пластин зростають в наступній послідовності: стан постачання $\rightarrow$ гартування + старіння $780^{\circ} \mathrm{C}, 10$ годин $\rightarrow$ гартування + старіння $780{ }^{\circ} \mathrm{C}$, 2 години $\rightarrow$ тільки гартування.

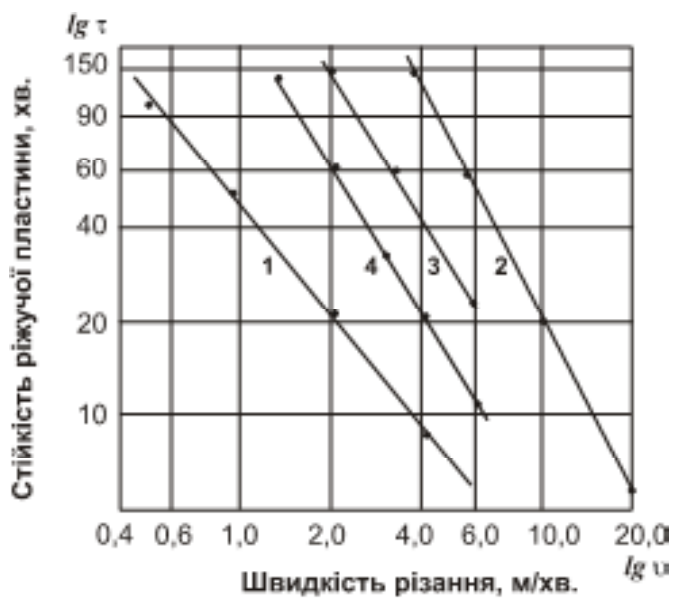

Рис. 1. Залежності стійкості інструменту від швидкості різання для різного стану сплаву:

1 - стан постачання (без термічної обробки); 2 - гартування $1150{ }^{\circ} \mathrm{C}, 2$ години, масло; 3 - гартування + старіння $780{ }^{\circ} \mathrm{C}$, 2 години; 4 - гартування + старіння $780^{\circ} \mathrm{C}, 10$ годин 
За даними рис. 1 можна визначити конкретні значення стійкості різальних пластин для обраної швидкості різання. Так при швидкості різання 4 м/хвилину відповідні значення стійкості різальних пластин в хвилинах мають таку послідовність: $9 \rightarrow 22 \rightarrow 41 \rightarrow 140$. Тобто найбільшу стійкість різальним пластинам забезпечує термічна обробка сплаву, що полягає тільки в гартуванні - 140 хвилин проти 9 хвилин в стані постачання.

Таким чином, згідно отриманим результатам, для кращої оброблюваності різанням заготовки із сплаву ХН35В6ТЮ (ЕК39) попередньо потрібно піддавати гартуванню. Така термічна обробка, порівняно зі станом поставки, зменшує витрати на різальний інструмент майже в 15 разів і, відповідно, робить використання сплаву замість серійних штампових сталей більш економічним. Отримані результати можуть бути використані і для інших сплавів з ГЦК кристалічною граткою, що зміцнюються $\gamma^{\prime}$ - фазою типу $\mathrm{Ni}_{3}(\mathrm{Al}, \mathrm{Ti})$, оскільки погана оброблюваність різанням є загальною їх особливістю.

\section{Список літератури}

1. ТУ 14-1-3416-82. Прутки кованные и катанные из жаропрочных сплавов на железоникелевой основе марок ХН35В6ТЮ (ЭК39) и ХН30ВМЮ (ЭК40).

2. Химушин Ф. Ф. Жаропрочные стали и сплавы / Ф. Ф. Химушин. - М. : Металлургия, 1969. - 749 с.

3. Обработка резанием жаропрочных, высокопрочных и титанових сплавов / [Н. И. Резников, Е. В. Бурмистров, И. Г. Жарков, А. С. Зыкин]. - М. : Машиностроение, 1972. - 200 с.

4. Петруха П. Г. Обработка резанием высокопрочных, коррозионностойких и жаропрочных сталей / [П. Г. Петруха, А. Д. Чубаров, Г. А. Стерлин и др.] - М. : Машиностроение, 1980. - 115 с.

Одержано 10.12.2020

(С) Канд. техн. наук Грабовський В. Я., Лисиця О. В. Національний університет «Запорізька політехніка», м. Запоріжжя

Grabovskii V., Lisitsa 0. Heat treatment as a method for improving the machinability by cutting of tool alloy with FCC lattice

\section{Рецензія на підручник* «Фазові рівноваги і фазові перетворення», опублікований заслуженим діячем науки і техніки України, доктором техн. наук, проф. Мазуром В. I.}

Тематика підручника відповідає навчальній програмі КПІ ім. І. Сікорського з дисципліни «Фазові рівноваги і фазові перетворення» для студентів спеціальності 132 Матеріалознавство.

В першій частині надаються основні поняття класичної термодинаміки рівноважного стану Дж. Гіббса. На відміну від поширеного, на жаль, в сучасній навчальній літературі поняття про стан фазової рівноваги як про ситуацію, в якій нічого не змінюється в системі при довгих витримках за даною температурою, автор повертає учня до поняття про хімічний потенціал даного атома в даній фазі і через це приводить до класичного формулювання умов фазової рівноваги в гетерогенній системі.

Формулюються основні положення геометричної термодинаміки, зокрема дається поняття про фазовий простір Гіббса.

Зважаючи на поширену але помилкову думку, що фазове перетворення починається при температурі фазової рівноваги, в підручнику вперше подано поділ фазових діаграм на діаграми фазових рівноваг і діаграми плавкості, де перший тип діаграми формулює теоретичні умови фазової рівноваги, а другий - отримані за результатами термічного аналізу умови фізичного співіснування фаз.

В другій частині надається аналіз основних типів діаграм фазових рівноваг та їх повний аналіз. Аналізуються також і основні помилки при побудові діаграм та надаються методи їх виправлення. В підсумку розділу показано методику аналізу складних фазових діаграм.

*V. Mazur. Phase equilibria and phase transformations. - Kyiv : Polytechnica. $-2020 .-212$ p. In English. ISBN 978-966-990-016-6.

(C) Ольшанецький В. Ю., 2020

DOI 10.15588/1607-6885-2020-1-14 